The Common Agricultural Policy of the European Union the present and the future

EU Member States

point of view 



\section{INSTITUTE OF AGRICULTURAL AND FOOD ECONOMICS NATIONAL RESEARCH INSTITUTE}

\section{The Common Agricultural Policy of the European Union - the present and the future}

\section{EU Member States point of view}

Editors:

dr Marek Wigier

prof. dr hab. Andrzej Kowalski

Proceedings of the International Scientific Conference

"The Common Agricultural Policy of the European Union - the present and the future" Multi-Annual Programme 2015-2019

"The Polish and the EU agricultures 2020+. Challenges, chances, threats, proposals" 5-7 December 2017 Stare Jabłonki, Poland

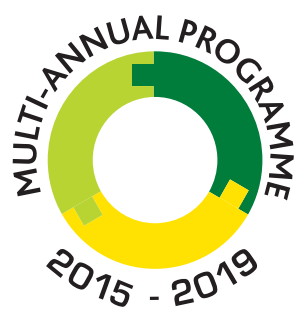

THE POLISH AND THE EU AGRICULTURES 2020+ CHALLENGES, CHANCES, THREATS, PROPOSALS

Warsaw 2018 
This monograph was prepared under the Multi-Annual Programme 2015-2019

"The Polish and the EU agricultures 2020+. Challenges, chances, threats, proposals".

The publication is a collection of selected papers delivered at the 22th edition of the International Scientific Conference organized by the Institute of Agricultural and Food Economics - National Research Institute. The theme of the conference was "The Common Agricultural Policy of the European Union the present and the future. The conference was placed on 5-7 December 2017 in Stary Jabłonki in Poland. Common Agricultural Policy was and still is one of the key pillars of European integration. Published in two volumes materials refer directly to the current and future of the CAP in EU and non EU member states, the strategic objectives and principles of agricultural policy for the agri-food sector and rural areas, address the issues of equilibrium between agriculture, forestry and land use, relate to the dilemmas for the EU budget and the CAP after 2020, CAP instruments and their adjustment, transformations of the rural economy and programming of the rural and agricultural policy, as well as productivity and production efficiency and tensions between sectoral action and between different models of territorial activities.

In the Scientific Committee of the Conference was participated: Prof. Andrzej Kowalski (IAFE-NRI, Poland), Prof. Drago Cvijanonivić (University of Kragujevac, Serbia), Prof. Thomas Doucha (IAEI, Czech Republic), Noureddin Driouech, PhD (CIHEAM, Italy), Prof. Szczepan Figiel (IAFE-NRI, Poland), Prof. Masahiko Gemma (Waseda University, Japan), Prof. Wojciech Józwiak (IAFE-NRI, Poland), Prof. Jacek Kulawik (IAFE-NRI, Poland), Prof. Yuriy Oleksiyovych Lupenko (IAE, Ukraina), Prof. Věra Majerová (CULS, Prague), Prof. Dimitre Nikolov (IAE, Bulgaria), Maire Nurmet, PhD (EMÜ, Estonia), Prof. Gabriel Popescu (ASE, Romania), Norbert Potori, PhD (AKI, Hungary), Prof. Włodzimierz Rembisz (IAFE-NRI, Poland), Piotr Szajner, PhD (IAFE-NRI, Poland), Prof. Alina Sikorska (IAFE-NRI, Poland), Prof. Jonel Subić (IAE, Serbia), Prof. Samuele Trestini (UNIPD, Italy), Prof. Olga Varchenko (Bila Tserkva National Agrarian University, Ukraine), Dipl.-Ing. Klaus Wagner (AWI, Austria), Marek Wigier, PhD (IAFE-NRI, Poland), Prof. Józef St. Zegar (IAFE-NRI, Poland)

In the Organising Committee of the Conference was participated: Małgorzata Bułkowska (IAFE-NRI, Poland), Anna Hankiewicz (IAFE-NRI, Poland), Joanna Jaroszewska (IAFE-NRI, Poland), Joanna Korczak (IAFE-NRI, Poland), Krzysztof Kossakowski (IAFE-NRI, Poland), Irena Mikiewicz (IAFE-NRI, Poland), Małgorzata Mikołajczyk (IAFE-NRI, Poland), Lech Parzuchowski (IAFE-NRI, Poland), Ewa Sierakowska (IAFE-NRI, Poland), Paulina Smakosz (IAFE-NRI, Poland), Leszek Ślipski (IAFE-NRI, Poland), Marek Wigier, PhD (IAFE-NRI, Poland).

Reviewers:

Professor Dimitre Nikolov, Institute of Agricultural Economics, Sofia, Bulgaria

Professor Gabriel Popescu, The Bucharest University of Economic Studies, Bucharest, Romania

Professor Samuele Trestini, University of Padva, Italy

Proofreader

Katarzyna Mikulska

Technical editors:

Joanna Jaroszewska, Barbara Pawtowska, Ewa Sierakowska, Kamila Tomaszewska,

Barbara Walkiewicz

Translated by

Summa Linguae S.A.

Cover Project

Leszek Ślipski

ISBN 978-83-7658-743-1

DOI: $10.30858 / \mathrm{pw} / 9788376587431$

Instytut Ekonomiki Rolnictwa i Gospodarki Żywnościowej

- Państwowy Instytut Badawczy

ul. Świętokrzyska 20, 00-002 Warszawa

tel.: (22) 5054444

faks: (22) 5054636

e-mail:dw@ierigz.waw.pl

http://www.ierigz.waw.pl 


\section{Contents}

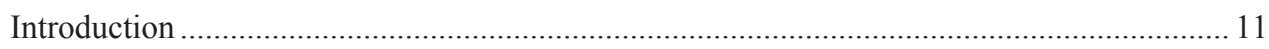

Dr Marek Wigier

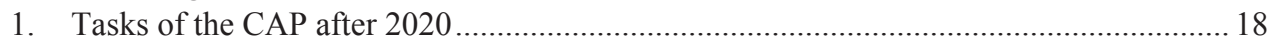

Dr hab. Julian Krzyżanowski

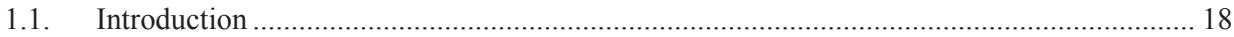

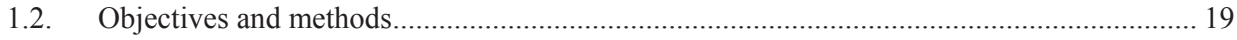

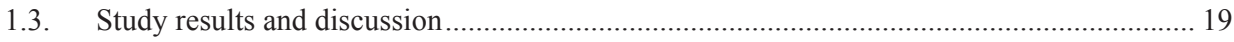

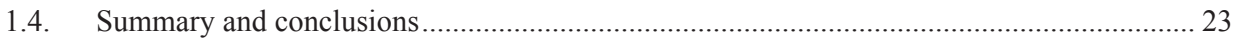

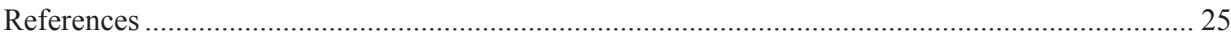

2. An assessment of the regional impacts of post-2020 CAP budgetary cuts on production

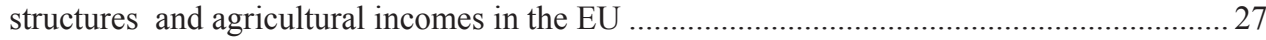

PhD Norbert Potori, PhD János Sávoly, PhD Szabolcs Biró

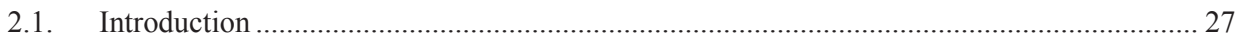

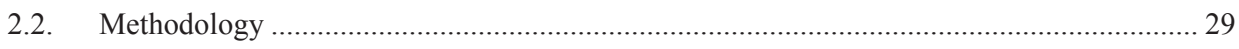

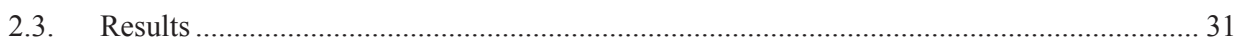

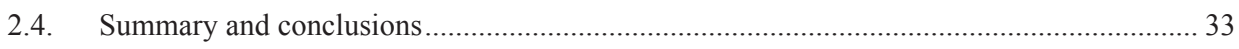

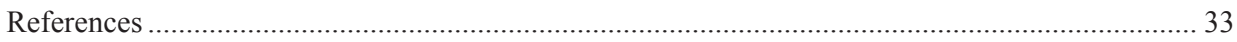

3. Is there room for financial instruments in the Common Agricultural Policy? Casus of

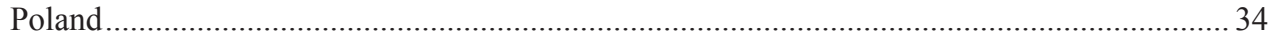

Prof. dr hab. Jacek Kulawik, PhD Barbara Wieliczko, PhD Michat Soliwoda

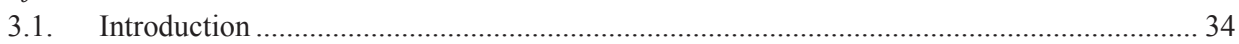

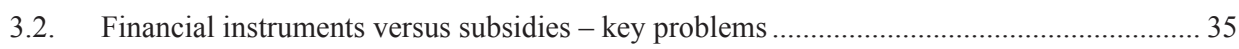

3.3. The use of financial instruments under the EU policy ......................................................... 37

3.4. Example of the use of FI in the 2014-2020 programming period ......................................... 38

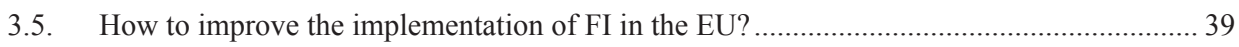

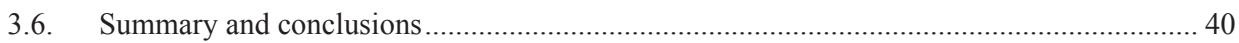

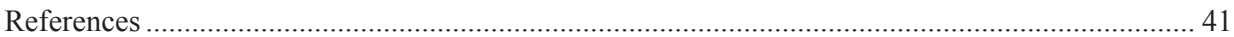

4. The past, present and future of the CAP - the Hungarian viewpoint ............................. 43

Dr Tamás Mizik

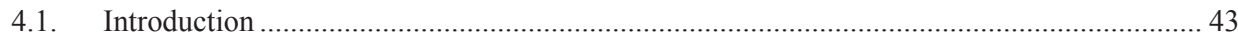

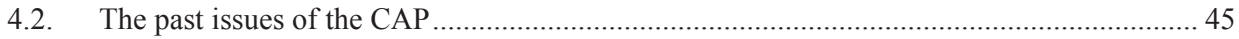

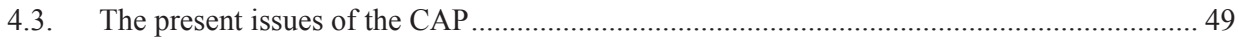

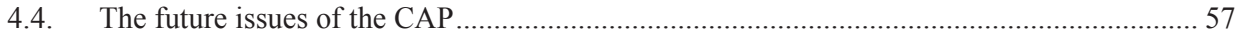

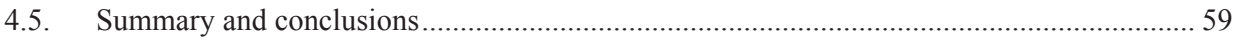

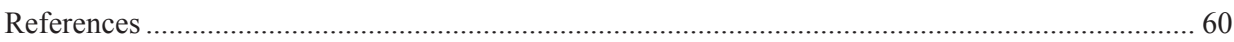


5. Going beyond the Rural Development Programme: a Master Plan for Austria's rural areas in the framework of the CAP

Dip.-Ing. Klaus Wagner

5.1. Introduction

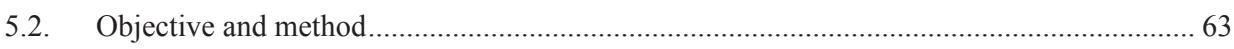

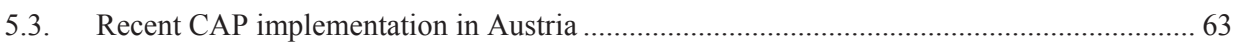

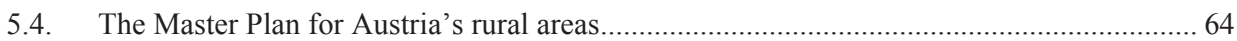

5.5. CAP in the system of the EU policy objectives and in the view of regional science

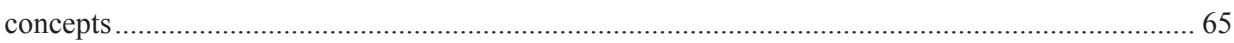

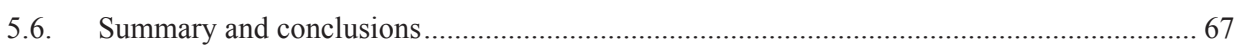

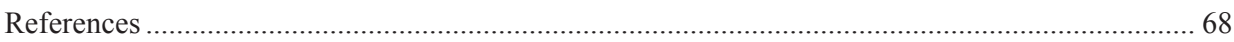

6. Possibilities to connect the Romanian agricultural research to the market requirements 69 Prof. Gabriel Popescu

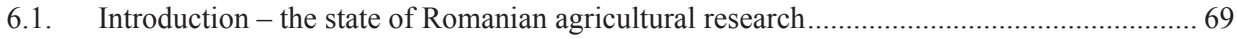

6.2. The problems faced by agricultural research since 1990 ..................................................... 71

6.3. Possible solutions for the recovery of Romanian agricultural research ................................ 76

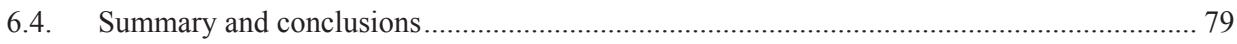

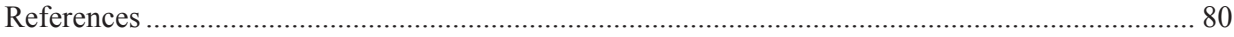

7. Price relationships of the production factors as exogenous determinants of production in agriculture.

Prof. dr hab. Włodzimierz Rembisz, PhD Adam Waszkowski

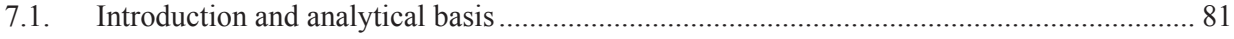

7.2. Relationships of prices of the capital, labour and land factors - hypothetical approach...... 83

7.3. Relationships of prices of the capital, labour and land factors - empirical approach .......... 84

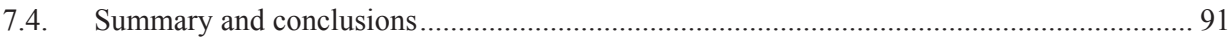

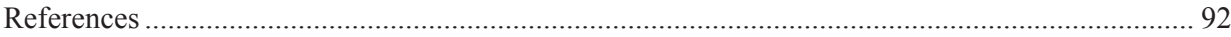

8. Effects of direct payments on agricultural development in Bulgaria ............................. 93 PhD Bozhidar Ivanov

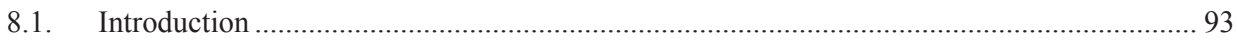

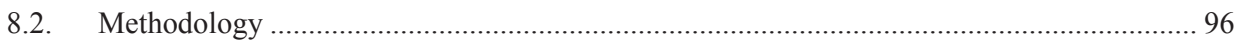

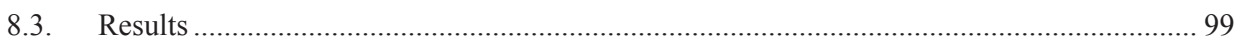

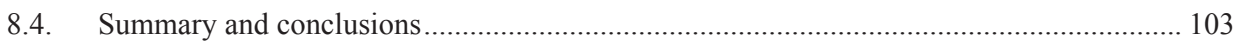

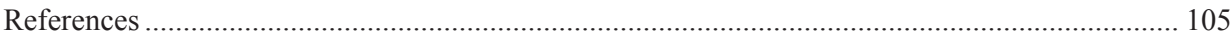

9. Re-adjusting risk management within the CAP: evidences on the implementation of the

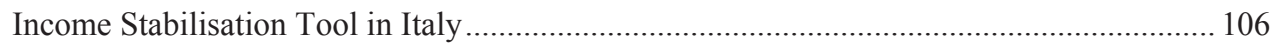
Prof. Samuele Trestini, PhD Elisa Giampietri

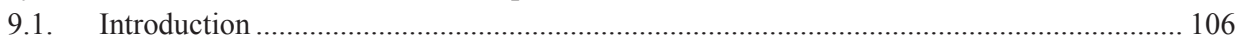

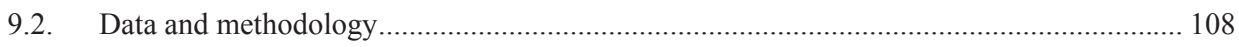




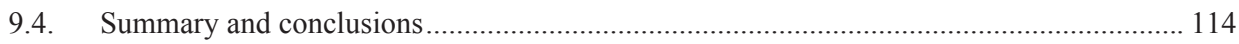

References

10. Comparison of risk management tools under the CAP of the EU, the US Farm Bill

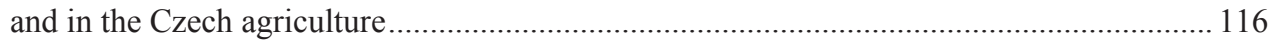
Ing. Václav Vilhelm, CSc., Ing. Sumudu Namali Gouri Boyinová, PhD Jindřich Špička

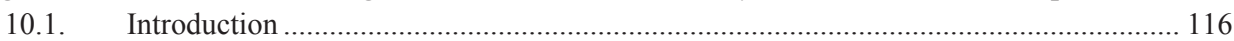

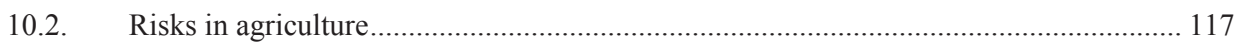

10.3. Risk management policy in the United States Farm Bill 2014 _..................................... 118

10.4. Risk management policy of the European Union's CAP ................................................ 119

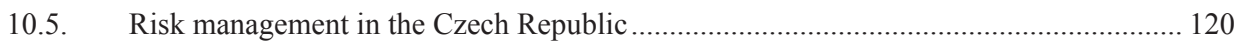

10.6. Comparative analysis of risk management policies ........................................................ 121

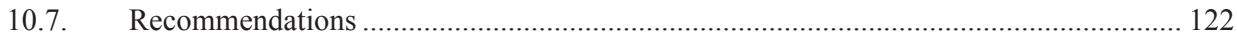

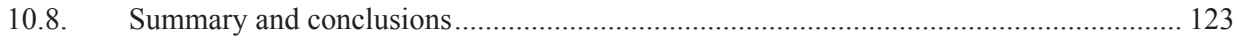

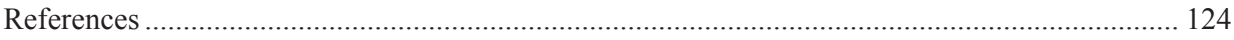

11. Factors determining the crop insurance level in Poland taking into account the level

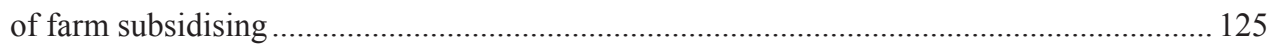

Prof. Adam Was, PhD Pawet Kobus

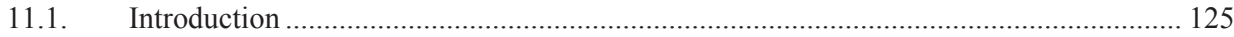

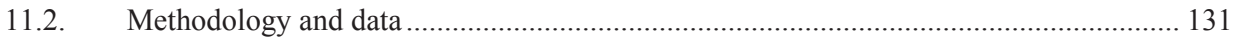

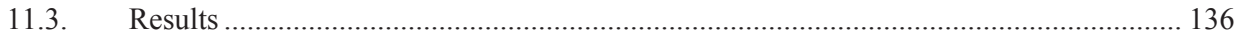

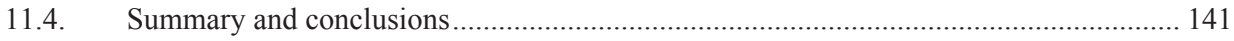

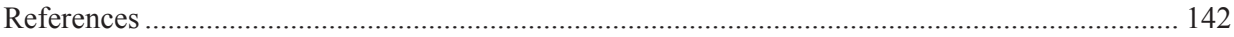

12. Farms and agricultural enterprises for development of sustainable and smart cooperatives: a multifactor approach using digital farm management ............................... 147 Prof. dr habil Adriana Mihnea, Prof. dr Dimitre Nikolov, dr Krasimir Kostenarov

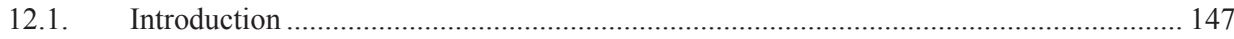

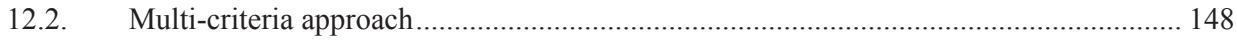

12.3. Construction of Farm Management Model ................................................................ 150

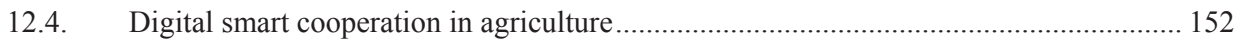

12.5. Application of the ANP Farm Management Model ....................................................... 154

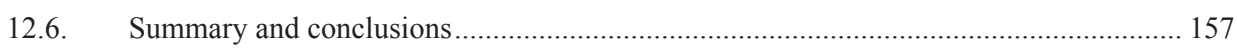

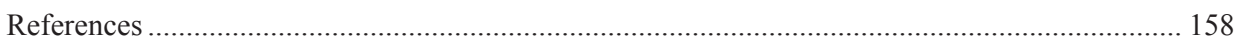

13. Brexit - potential implications for the Polish food sector .............................................. 159

Dr Katarzyna Kosior, Dr Łukasz Ambroziak

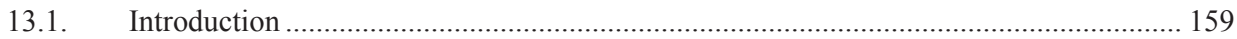

13.2. Negotiations on Brexit - what should be the model of the future relations? ..................... 161

13.3. The future of the EU finances and the CAP in the context of Brexit .............................. 163 
13.4. Impact of possible changes in the CAP budget on the net balance of Poland and transfers to the Polish agriculture.

13.5. The potential impact of Brexit on agri-food trade between Poland and the United

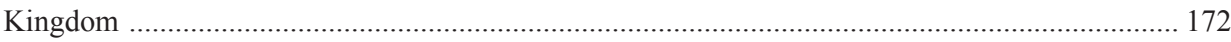

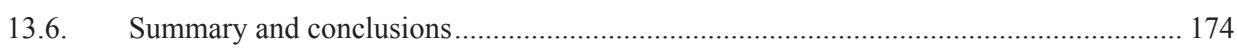

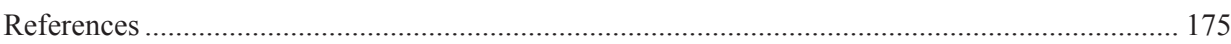

14. The Transatlantic Trade and Investment Partnership (TTIP): a threat or an opportunity for the EU-Mediterranean agriculture and agri-food sector? An exploratory survey ........... 177 Dipl.-Ing. Katja Pietrzyck, PhD Noureddin Driouech, Prof. Brigitte Petersen

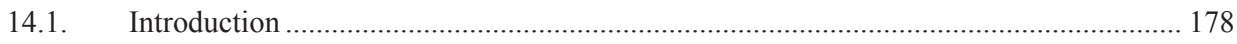

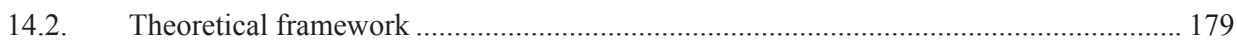

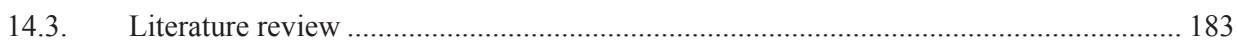

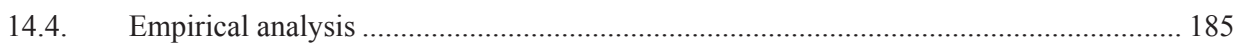

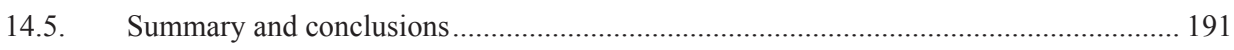

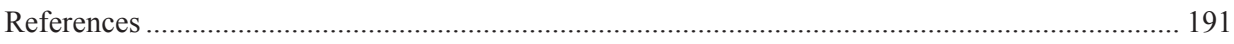

Appendix I: Overview of trade statistics regarding selected products ........................................... 195

15. The concept of short supply chains in the food economy............................................. 196

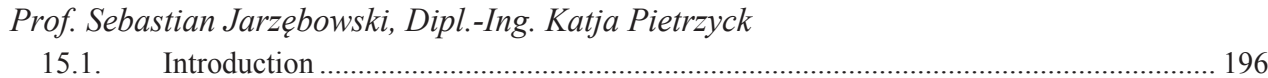

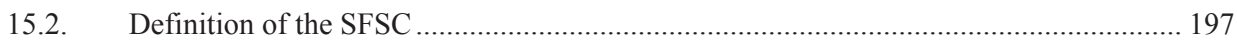

15.3. Development of short supply chains in Europe............................................................. 201

15.4. Global context of European short supply chains ........................................................... 205

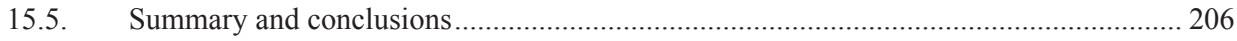

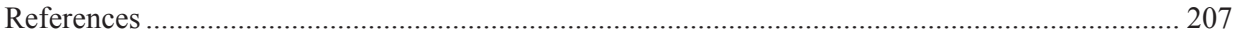

16. The CAP implementation in Wallonia - today performance and questions for the future -

A brief supplementary comment from Warmia and Mazury perspective............................. 209

PhD Philippe Burny, PhD Benon Gazinski

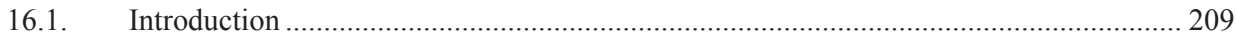

16.2. Implementation of the green payment in Wallonia in 2015 ........................................ 210

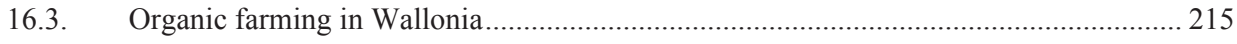

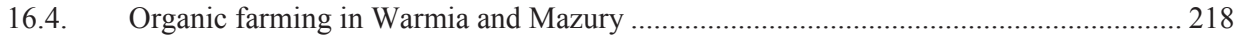

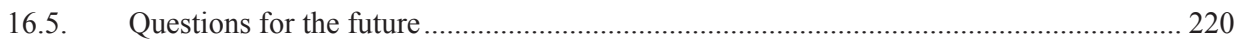

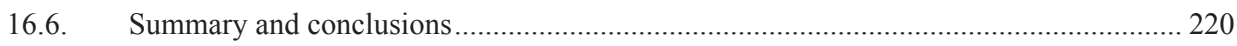

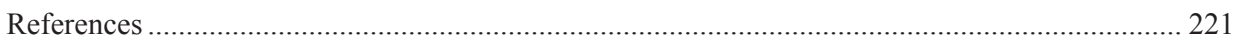

17. Afforestation of agricultural land financed from the RDP 2014-2020 ....................... 224

PhD Marek Zieliński

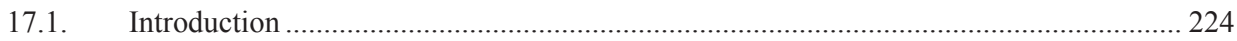

17.2. Natural farming conditions in Poland in regional terms................................................. 225 
17.3. The impact of natural farming conditions in Poland on the economic situation and the possibility of afforestation on farms

17.4. Land afforestation financed from the RDP 2014-2020 in regional terms

17.5. Importance of land afforestations financed under the RDP 2014-2020 in the EU climate policy for 2021-2030.

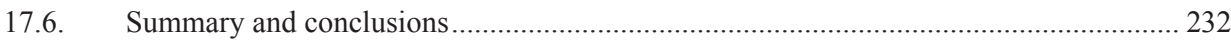

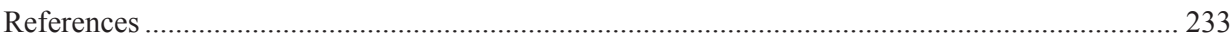

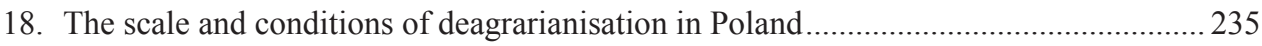

PhD Michat Dudek, PhD Bożena Karwat-Woźniak

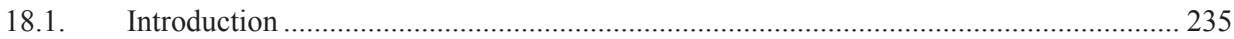

18.2. The conditions of the decrease in employment in agriculture ......................................... 236

18.3. The change in the scale of employment in agriculture in Poland and its conditions....... 238

18.4. The instruments of the Cohesion Policy and agriculture and rural development of the EU

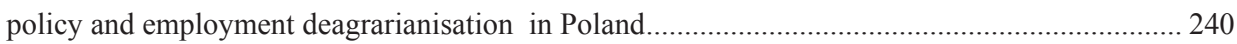

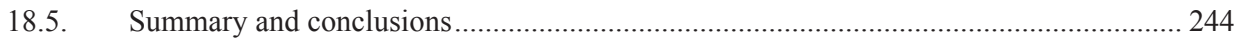

References 245

19. Socio-economic and environmental parameters and results of rural development under the CAP: the case of Bulgaria ................................................................................................ 247 Prof.dr.hab. Julia Doitchinova, Prof.dr.hab. Ivan Kanchev, Ass.Prof. Ralitsa Terziyska PhD, Ass.Prof. Kristina Todorova PhD

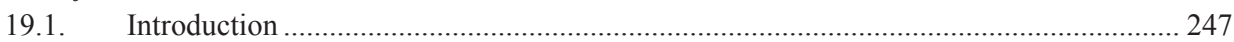

19.2. Changes in Bulgarian rural areas - socio-economic and environmental aspects................ 248

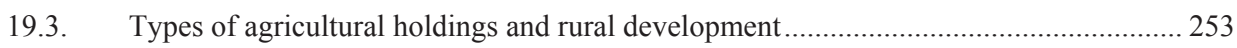

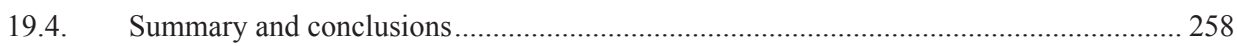

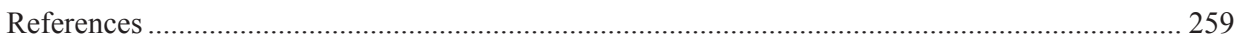

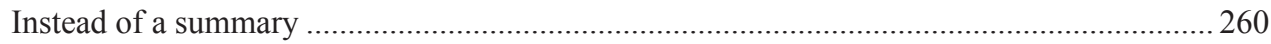

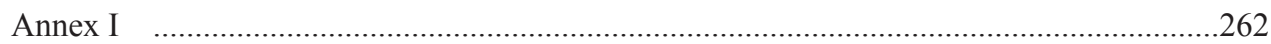




\title{
11. Factors determining the crop insurance level in Poland taking into account the level of farm subsidising
}

\author{
Prof. Adam Was ${ }^{1}$, PhD Pawet Kobus ${ }^{2}$ \\ ${ }^{1}$ Institute of Agricultural and Food Economics - National Research Institute, \\ Warsaw, Poland \\ ${ }^{2}$ Szkoła Główna Gospodarstwa Wiejskiego, Warsaw, Poland \\ was@ierigz.waw.pl,pawel_kobus@sggw.pl
}

DOI: $10.30858 / \mathrm{pw} / 9788376587431.11$

\begin{abstract}
Despite efforts and pressures on the part of the State, the relatively small percentage of Polish farmers insure their crops. The paper analysed the determinants of taking out crop insurance, using logistic regression and FADN data (2004-2013). The models were estimated for the analysed population and by groups with a different subsidy rate. A novelty is the use of the Horvitz-Thompson estimator which allows us to generalise the results of the models on a national scale.

It was found that crop insurance was mainly determined by received compensation and significant losses in the past yields, as well as by: value of the agricultural production, crop production intensity and soil quality. The results obtained in this part are consistent with the expected utility hypothesis.

The impact of the level of subsidies received by farmers on insurance crop decisions was not confirmed, however, the models assessed for farms with a different subsidy rate point to the importance of subsidies as an income stabilising factor.
\end{abstract}

Keywords: crop insurance, agriculture subsidisation, income stabilisation, risk management

JEL codes: G22, Q14, G32, G18, Q11

\subsection{Introduction}

Since 2008, crop insurance in Poland was obligatory for farmers receiving direct payments. Farmers must insure at least $50 \%$ of their farmland. The relatively small percentage of insured crops raises the question of what factors determine farmers' decisions on crop insurance.

This problem was noticed by the European Commission [2001, 2006, 2011], as a result of which a possibility of subsidising crop insurance under the Rural Development Programme was introduced, in an amount of up to $65 \%$ of the contributions [European Commission, 2013], which was to encourage farm- 
ers to join the insurance system and thereby to ensure a sufficiently high participation rate necessary to guarantee the high efficiency of the system.

In Poland, the government did not make use of the opportunities created by the European Commission under the RDP, but also attempted to increase the insurance coverage for the crop production through a nationally-financed subsidy system. In addition, since 2008, crop insurance was obligatory for farmers receiving the EU payments. Almost all Polish farmers are required to insure at least $50 \%$ of their farmland. In 2013 , however, only $10.8 \%$ of the total number of farmers insured their crops in the area accounting for $23.88 \%$ of arable land. This happens despite the fact that, according to the Polish law, farmers who do not take out any insurance are required to pay a penalty of EUR 2 per ha. The penalty is relatively small when compared to the lowest subsidised contribution of EUR 10 per ha (winter wheat $7 \mathrm{t} / \mathrm{ha}$, insurance against hail). Many farmers decide not to insure their crops, taking into account the fact that local authorities responsible for the collection of penalties are reluctant to enforce this obligation.

Despite limiting factors such as the adverse selection [Goodwin, 1993; Sherrick et al., 2004; Smith and Baquet, 1996; Velandia et al., 2009], moral hazard [Mishra et al., 2005; Smith and Goodwin, 1996], which together may lead to an increase in information asymmetry [Esuola et al., 2007] or fraud [Roth and McCord, 2008], the agricultural insurance offer continues to develop thanks to state subsidy programmes [Bielza Diaz-Caneja et al., 2009]. This note also applies to Poland, where the first subsidised insurance scheme was introduced in 2005.

The Ministry of Agriculture and Rural Development signed an agreement with 5 major insurance companies active in the agricultural insurance market, which were designated to introduce subsidised agricultural insurance pursuant to the Act on crops and livestock since 7 July 2005. The maximum level of the contribution for each insurance eligible for co-financing $\mathrm{w}$ set at $6 \%$ of the insurance amount.

In addition to crop insurance, farmers in Poland are required to take out civil liability insurance due to managing a farm and insurance for farm buildings against fire and natural disasters. Pursuant to the data published by the Central Statistical Office [GUS, 2015; GUS, 2016], it can be concluded that the number of civil liability insurance contracts in agriculture in 2013 was 1465 thousand and was higher than the total number of farms (1429 thousand). In the case of farm buildings, the number of insurance contracts was even higher (1931 thousand of insurance policies). This means that almost all farmers have at least one contract with an insurance company during the year. Given the fact that the major insurance companies signed the aforementioned agreement with the Ministry of Agriculture, it can be assumed that most Polish farmers have access to crop insurance at least for the 
most serious risks. Thus, the problem of the low uptake of crop insurance in Poland does not result from the lack of access to offered insurance. As the level of the uptake of insurance policies in Poland is still very low, the authors set for themselves an objective to analyse the determinants influencing the decisions of Polish farmers on crop insurance, based on the production data at the farm level and the accounting data available in the FADN (Farm Accountancy Data Network), with particular consideration to the farm subsidy rate as a factor potentially differentiating the decisions of farmers on taking out crop insurance. The paper uses logit regression to define the factors determining taking out any crop insurance by the farmer.

The typical determinants of the demand for any good in the market can be defined as: "own price of the good, price of substitutes, income level, consumer expectations about future prices or incomes and tastes and preferences or complementary goods" [Parkin et al., 2002].

As regards taking out insurance, classic analysis of the demand for crop insurance may be carried out taking into account the following components:

\section{$\underline{\text { Risk level: }}$}

- Crop variability,

- Weather conditions,

- Income variability,

- Farm debt level,

- $\quad$ Expected level of compensation.

\section{Available substitutes:}

- Production techniques e.g. irrigation,

- Participation in mutual funds,

- $\quad$ Subsidy rate of operating activities.

\section{Farmer's preferences:}

- Experience in managing a farm,

- Level of education,

- Experience with insurers,

- Level of risk perception,

- Level of risk aversion.

\section{Income level:}

- $\quad$ Farm income level.

\section{Price level}

- Amount of the insurance contribution. 
The price of the good, in the case of insurance, is the amount of a contribution paid by the farmer. Theoretically, the higher is the price, the lower should be the demand for the good. However, there are many studies showing that the demand for crop insurance is inflexible [O'Donoghue, 2014; Coble and Barnett, 2013; Shaik et al., 2008; Goodwin et al., 2004; Serra et al., 2003; Coble et al. 1996; Goodwin, 1993]. As regards the subject of analysis, it should be concluded that the contribution paid for specific insurance depends on many factors, e.g. on the characteristics of the region, and even on the characteristics of the farm, type and number of crops covered by insurance and, finally, on the value of the production insured. In reality, the real insurance price is a difference between expected compensation (in the case of losses) and paid contribution - the expected return on crop insurance. This value can only be provided based on the historical data regarding specific crop insurance, but this price cannot be determined when considering taking out any crop insurance.

The availability of cheap substitutes reduces the demand for the given good because customers are more likely to purchase a substitute. In the case of crop insurance, it is more difficult to identify substitutes than in the case of tangible goods. Assuming, however, that the main purpose of insurance is to stabilise income from the agricultural production and to secure the current level of consumption of the family, irrespective of a possibility of losses in crop yields, many activities with similar effects may be considered a substitute. Consequently, the cost of using other risk management methods can be treated as a price of substitute. The diversification of production [Smith and Glauber, 2012; Tsikirayi et al., 2013] results in the lower risk at the expense of lower economies of scale within a single farm. Participation in investment funds [Meuwissen et al., 2013; Sulewski et al., 2014] leads to risk sharing at the expense of supporting other farmers who suffer serious losses. Traditionally, a substitute for any insurance is the accumulation of savings [Farrin et al., 2016], which also means incurring some alternative costs. The use of appropriate farming practices can significantly reduce the production risk. A spectacular example is irrigation [Heerman et al., 2016, p. 29], which significantly reduces the risk of drought in the crop production, but requires investment and operational inputs. The potential availability of public-funded ad hoc compensation for losses in crops [Liesivaara and Myyrä, 2017] can be considered as a substitute for efforts made to stabilise income and, consequently, reduce the level of crop insurance. Moreover, in particular in relation to the EU countries, subsidies to operating activities, in particular direct payments, are often mentioned as an income stabilisation instrument. Income of farmers receiving payments is less dependent on the production performance and market factors. This is particularly important in farms with a high subsidy rate for income [Kulawik and Płanka, 2013; Majewski and Wąs, 2009]. 
As regards the price risk, the literature points to futures contracts as an instrument for securing the level of crop income [Sherrick and Schnitkey, 2016]. Also, contracts with the buyer, e.g. "Marketing contracts" and "Production contracts" [Vavra, 2009] can be considered as an income stabilisation tool. However, bearing in mind the objective of this paper, i.e. analysis of taking out crop insurance, income stabilisation instruments were not analysed, while focusing more on insurance of crops against the production-related risk.

The income level is one of the important factors when analysing the demand for any goods. It is mentioned in the literature as one of the factors determining the uptake of insurance. However, income as a determinant of crop insurance may be examined in two aspects. The income level determines the farmer's wealth. From this point of view, the low income level, especially when farmers have to pay loans, can reduce the level of taking out crop insurance [Tsikirayi et al., 2013, p. 7]. On the contrary, the high income level gives more opportunities to increase wealth and maintain capital reserves helping to survive a poor year, even without payment of compensation. It can be concluded that "crop insurance is something that low-wealth farmers cannot afford and high-wealth farmers do not want" [Farrin et al., 2016, p. 5[.

On the other hand, in addition to the absolute income level, its variability and expectations as to future income may be a significant factor affecting the use of crop insurance. This aspect can be clarified based on the expected utility hypothesis by von Neumann-Morgenstern. Insurance is more attractive to farmers with high risk aversion and in situations where the risk justifies payment of contributions significantly higher than the expected loss without insurance [Hardaker et al., 1997; Mohammed and Ortmann, 2005]). This is particularly important in the case of high-value losses that could undermine the financial stability of a farm [Farrin et al., 2016]. Similarly, the amount of expected compensation and the probability of receiving it [Tsikirayi et al., 2013] are factors which increase the utility of taking out insurance. The higher expected profitability level corresponding to the expected production value [Tsikirayi et al., 2013] tends to increase the expected loss value due to adverse conditions and, therefore, it is also a factor which should increase the uptake of insurance. Similarly, the expected adverse weather conditions [Turvey and Kong, 2010; Liu et al., 2010; Kong et al., 2011] tend to increase the perception of farmers as to the expected loss value and thereby increase the uptake of crop insurance. The farm debt level may also determine decisions on taking out insurance. The necessity of debt servicing increases uncertainty as to the future financial situation of the farm and, therefore, the utility of potential compensation is higher in farms with the higher assets debt level. 
While it is difficult to measure "tastes and preferences" regarding crop insurance, the literature lists a number of variables that affect these preferences: age of the farmer, experience and level of education of the farmer, as well as the size of farmland, risk aversion or satisfaction with previous insurance policies [Tsikirayi et al., 2013]. These are factors determining the farmers' assessment as to future expectations. With regard to the age of the farmer, there is no conclusive evidence of its impact on the decision on taking out insurance. Masara and Dube [2017] prove a positive effect of the age of farmers on taking out crop insurance based on their observation in Zimbabwe, while Sadati et al. [2010], as well as Mahammed and Ortmann [2005] and Akinola [2014] claim that older, and thus more experienced, farmers can handle the risk without insuring crops.

The scale of activity also has a positive impact on the uptake of insurance [Afroz et al., 2017]. This is consistent with the results of many studies [Goodwin, 1993; Barry et al., 2001; Goodwin and Mishra, 2006], according to which the farm size was positively correlated with the decision on taking out crop insurance. It should be stressed that the choice and signing of an insurance contract is a complex decision which, if is to be reasonably made, requires farmers to carry out complex and multifaceted analysis. The effort is even greater if the farmer needs to submit an application for compensation. This effort has the nature of a permanent cost. Owners of small farms where the total value of expected losses is relatively low, are less likely to make these efforts.

It is also worth stressing that the use of agricultural insurance may be associated with the risk perception and risk aversion of farmers. The risk assessment for farmers is a prerequisite for the choice of a risk management strategy because the farmer who is not aware of the risks is not able to manage them effectively [Sulewski and Kłoczko-Gajewska, 2014a]. The risk perception by farmers, which may result from losses suffered in the past, potentially increases the uptake of insurance [Adtiya et al., 2016]. Even farmers who are aware of all potential risks may behave differently because of their attitude towards risk. Sulewski and Kłoczko-Gajewska [2014b] and Heerman et al. [2016] stated that farmers who insured their crops were characterised by greater risk aversion.

In classical analysis of demand, the factor determining the decision on taking out insurance is the situation in the market of complementary goods, the demand for which is connected with the demand for the given main good. In this context, it is possible to analyse the situation where crop insurance required by a financing institution as loan collateral can be used as an example. The existence of such conditions in the market may lead to an increase in the demand for agricultural insurance [Tsikirayi et al., 2013]. 
Strong resistance of Polish farmers to taking out crop insurance gives rise to a question about the determinants affecting the decisions of farmers in this regard. In the previous studies on the conditions of taking out crop insurance in Poland [Stempel, 2013; Wicka et al., 2013], the authors concluded that the key factors determining the decisions on taking out crop insurance are: farm size, level of education and experience of the farmer, share of the crop production in the value of agricultural sales and the income level. However, due to the fact that this analysis does not include the information about the number of farms represented by each farm in the sample used for studies, their results cannot be considered representative of the entire population of Polish farms.

\subsection{Methodology and data}

In order to analyse the determinants of the decisions on crop insurance, the authors constructed a logistic regression model based on the FADN sample. The accounting data of famrs belonging to the FADN network has been collected in Poland from the moment of accession to the European Union in 2004. It is well-known that in the case of applying quantitative methods, the quality of results depends on the size of the analysed sample. In this case, the FADN sample, especially if a period of 10 years is analysed, is one of the best possible data sources for this analysis. The sample of farms is composed of about 11-12 thousand farms in each accounting year. In accordance with the data collection rules in the FADN system, the farm sample represents at least $90 \%$ of the agricultural production in each EU country. In Poland, the FADN sample represents about 731 thousand farms, which accounts for about $50 \%$ of all farms and nearly $80 \%$ of the utilised agricultural area. Depending on the structure and overall value of the standard output (SO), farms are divided according to the production type and economic size. For the purposes of this analysis, the typology of farms from 2008 [European Commission, 2008] was used.

The primary source of data for the study was the sample of FADN farms of 2013. However, the data on losses in yields, received compensation and the rate of risk aversion of farmers were determined using the data of farms which were present in the FADN sample for at least 4 years in the period from 2004 to 2012. The following types of farms were identified: cereal (TF15), mixed cropping (TF16), cattle (TF45-48), mixed livestock (TF73-74) and mixed (TF 83-84). Poultry and pig farms were not analysed, because the crop production could have been seen as the marginal activity on these farms. Similarly, specialised fruit and vegetable farms were not taken into account because of the variety of crops and the particularly high risk associated with the horticultural production. 
As far as the economic size of farms is concerned, the smallest farms with the economic size of less than EUR 8000 of standard output (SO) were excluded from the sample. It was considered that these farms are mainly a place of residence and an additional source of income for farmers, and not any commercial activities. In total, 5202 farms of the total number of 12117 of individual farms included in the FADN sample were taken into account in 2013. The reduction in the number of farms resulted from the selection of specific production types, economic size classes and exclusion of farms which were present in the FADN sample for less than 4 years in 2004-2012. The reason for applying the criterion of presence in the sample for at least 4 years was a need to estimate the occurrence of yield losses and risk aversion in farmers. The number of farms in the FADN sample of 2013 in each identified class, taking into account the location in the FADN regions, is shown in Table 1.

Table 1. Number of analysed farms in the FADN sample in Poland in 2013

\begin{tabular}{|l|c|c|c|c|c|}
\hline & $\begin{array}{c}\text { Cereal } \\
\text { (TF15) }\end{array}$ & $\begin{array}{c}\text { Mixed } \\
\text { cropping } \\
\text { (TF16) }\end{array}$ & $\begin{array}{c}\text { Cattle } \\
(\text { TF 45-48) }\end{array}$ & $\begin{array}{c}\text { Mixed } \\
\text { livestock } \\
\text { (TF 73-74) }\end{array}$ & $\begin{array}{c}\text { Mixed } \\
\text { (TF83-84) }\end{array}$ \\
\hline $\begin{array}{l}\text { Pomorze and Mazury } \\
(785)\end{array}$ & 300 & 116 & 209 & 57 & 242 \\
\hline $\begin{array}{l}\text { Wielkopolska and } \\
\text { Śląsk (790) }\end{array}$ & 586 & 337 & 270 & 180 & 769 \\
\hline $\begin{array}{l}\text { Mazowsze and } \\
\text { Podlasie (795) }\end{array}$ & 178 & 227 & 521 & 114 & 569 \\
\hline $\begin{array}{l}\text { Małopolska and } \\
\text { Pogórze (800) }\end{array}$ & 100 & 102 & 89 & 35 & 201 \\
\hline Total & 1164 & 782 & 1089 & 386 & 1781 \\
\hline
\end{tabular}

Source: Own study based on the FADN data.

As for geographical criteria, in Poland four FADN regions are identified and each is made of four NUTS 2 regions (Fig. 1).

The number of farms in each FADN region was as follows: "Pomorze and Mazury" - 924 farms of the total number of 1823 farms in the FADN sample; "Wielkopolska and Śląsk" - 2142 analysed farms of the total number of 4367; "Mazowsze and Podlasie" - 1609 analysed farms of the total number of 4498; "Małopolska and Pogórze" - 527 analysed farms of the total number of 1429. 
Figure 1. FADN regions in Poland

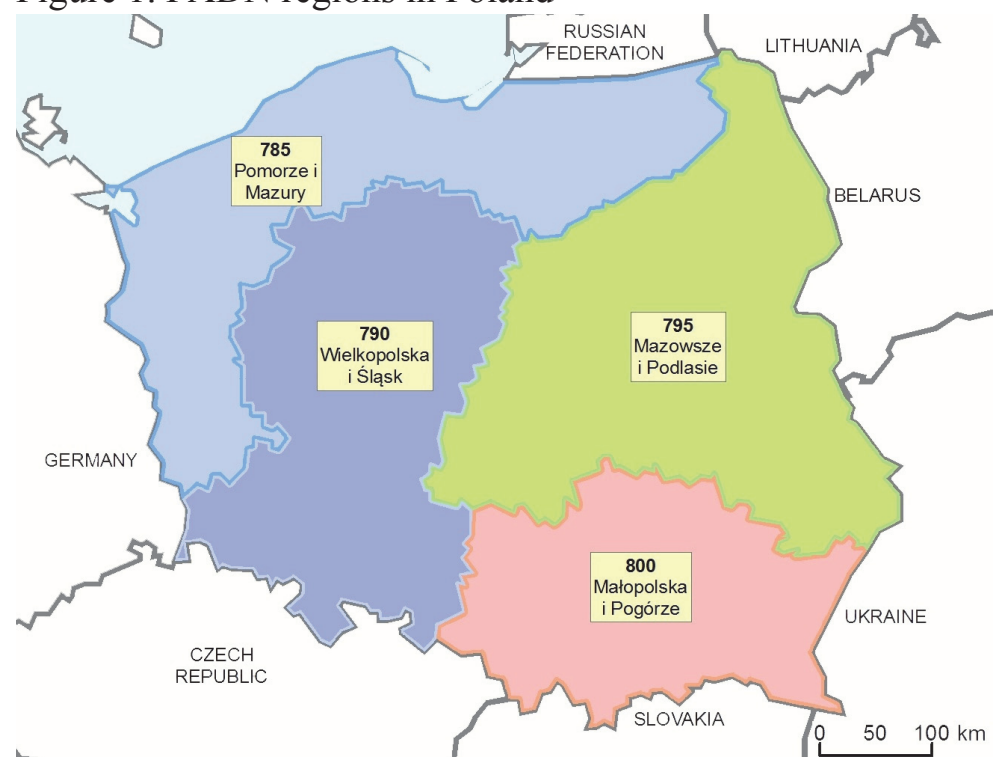

Source: European Commission Regulation 1291/2009.

A dependent binary variable described the use of at least one type of crop insurance ( 1 - use of crop insurance, 0 - no crop insurance). In the analysed group, $29.18 \%$ (19.47\% in the population) of farmers had crop insurance. Given that the Polish FADN sample is representative of about 50\% of all farms (the second half is made up of small, often partly self-subsistence, farms which largely do not bring any yields), this number seems to be in line with the official reports. The logistic regression model was used for analysis:

$$
\ln \left(\frac{P\left(Y_{i}=1\right)}{1-P\left(Y_{i}=1\right)}\right)=\alpha+\beta_{1} x_{1 i}+\mathrm{L}+\beta_{k} x_{k i}
$$

where:

$Y_{i}$ - dichotomous variable describing the fact of taking out crop insurance: 0 - not taken out, 1 - taken out,

$\alpha$ - absolute term, $x_{1 i}, \mathrm{~K}, x_{k i}-$ values of independent variables for the $i^{\text {th }}$ farm, $\beta_{1}, \mathrm{~K}, \beta_{k}$ - values of coefficients for individual independent variables.

The regression models were estimated for the entire analysed population and broken down into quartile groups identified based on the subsidy rate, measured as a ratio of the value of subsidies to operating activities to the production value (respectively, $<14.9 \% ; 14.9 \%-22.8 \% ; 22.6 \%-34.5 \% ;>34.5 \%$ ). 
Due to stratified sampling in the FADN, which was intended to ensure representativeness of the sample given the production type, economic size of the farm and FADN region, for assessing the model the Horvitz- Thompson estimator was used, thanks to which during the estimation of the models the estimate information on the number of farms represented by each farm in the sample was taken into account. In the event of exogenous sampling probabilities, weighing may be unnecessary for conformity and adverse to precision [Wooldridge, 1999]. However, the Neyman optimal allocation method used in the FADN makes the sampling probabilities strongly dependent on exogenous variables. For example, the correlation coefficient for the probability of sampling and production value is 0.63 . In such cases, the use of information about the number of actual farms represented by each farm in the sample is necessary for the compliance of the regression parameter estimators [Solon et al., 2015].

Table 2. Set of independent variables in relation of the concept of the analysis

\begin{tabular}{|c|c|c|}
\hline \multicolumn{2}{|c|}{$\begin{array}{l}\text { Factors potentially determining the crop } \\
\text { insurance level }\end{array}$} & Variables used in the model \\
\hline \multirow{6}{*}{ Risk level } & Crop variability & $\begin{array}{c}\text { Experiencing a significant }(>40 \%) \\
\text { yield decrease in } 2004-2012 \\
\text { Soil quality index [0.05-1.95] }\end{array}$ \\
\hline & Weather conditions & Location in one of the FADN regions \\
\hline & Income variability & $\begin{array}{c}\text { Crop production intensity } \\
\text { [value of inputs PLN thousand /ha] }\end{array}$ \\
\hline & Farm debt income & Debt ratio (total liabilities/total assets) \\
\hline & Expected level of compensation & $\begin{array}{l}\text { Receiving compensation at least once } \\
\text { in 2004-2012 }\end{array}$ \\
\hline & Farm size & Farm output value \\
\hline \multirow{3}{*}{$\begin{array}{l}\text { Available } \\
\text { substitutes }\end{array}$} & $\begin{array}{l}\text { Level of subsidisation of oper- } \\
\text { ating activity }\end{array}$ & $\begin{array}{l}\text { Subsidy rate equal to the quotient of subsidies } \\
\text { to operating activity and production value }\end{array}$ \\
\hline & $\begin{array}{l}\text { Production techniques - irriga- } \\
\text { tion }\end{array}$ & $\begin{array}{l}\text { Not included in the model } \\
\text { Not applicable to Polish farms }\end{array}$ \\
\hline & Participation in mutual funds & $\begin{array}{c}\text { Not included in the model } \\
\text { Not applicable to Polish farms }\end{array}$ \\
\hline $\begin{array}{l}\text { Income } \\
\text { level }\end{array}$ & Farm level income & Farm income [PLN thousand/year] \\
\hline \multirow{5}{*}{$\begin{array}{l}\text { Farmer's } \\
\text { preferences }\end{array}$} & Experience in managing a farm & Age of the farmer [years] \\
\hline & Level of education & $\begin{array}{l}\text { Level of education of the farmer [1 }=\text { at least } \\
\text { secondary] }\end{array}$ \\
\hline & Experiences with insurers & Receiving compensation in 2004-2012 \\
\hline & Level of risk perception & $\begin{array}{c}\text { Experiencing a significant }(>40 \%) \\
\text { yield decrease in } 2004-2012\end{array}$ \\
\hline & Level of risk aversion & Arrow-Pratt absolute risk aversion coefficient \\
\hline Price level & $\begin{array}{l}\text { Amount of the insurance con- } \\
\text { tribution }\end{array}$ & Not included in the model. \\
\hline
\end{tabular}

Source: own study. 
Based on the factors which may be determined according to the FADN sample and affecting the uptake of crop insurance, the following variables have been selected for empirical verification (Table 2).

Some variables included in the model require an additional description. In particular, the method used to calculate the Arrow-Pratt absolute risk aversion coefficient. The values of this coefficient were calculated based on production decisions of farmers registered with the FADN 2004-2012 database. The method used consists of several stages, the first of which is to develop a model explaining income according to the levels of inputs (e.g. costs of fertilisers, seeds, pesticides, labour input) and then to estimate two other models: one explaining the effect of the analysed variables on the square and cube residuals from the income model. The next step was to calculate the marginal effect of each input factor on the first 3 conditional profit moments and to estimate the FOC (first order conditions) system of equations using the calculated marginal effects for all analysed factors. A seemingly unrelated regression (SUR) model was used for this purpose. The estimation of the FOC system of equations has been carried out separately for each farmer. A detailed description and derivation of the procedure can be found in the original paper by Antle [1987] and in the specific application for assessing the Polish farmer's attitude regarding risk [Kobus and Wąs, 2017].

Other differentiated variables were defined in accordance with the methodology adopted in the FADN [European Commission, 2008]. In particular, farm income was calculated as a difference between the value of the agricultural production in a given year and the value of all means of production used, with the exception of unpaid labour costs and interest on net worth. The value of the agricultural production was used as an indicator of the economic size of the farm. The performance losses recorded in the last 9 years (2004-12) were defined as at least the $40 \%$ reduction in the yields below the on-farm average for at least one of main crops. Approximately $25.97 \%$ of farmers in the population represented by the data set have experienced at least one such loss over the analysed period. The $40 \%$ loss level was determined by the sensitivity analysis of the variable's predictive power.

A number of determinants mentioned in conceptual analysis have not been applied in the model. As already mentioned, the information about insurance prices or returns on contributions was not available at the farm level. Contributions to insurance policies in Poland depend primarily on insured crops and the type of risk covered. In 2015, the price of crop insurance against hail for spring cereals ranged from $0.39 \%$ to $2 \%$ of the insured amount, while for maize it was between $0.35 \%$ and $5 \%$. The costs of insurance against spring damage in the case of maize, sugar beet and potatoes ranged from $1 \%$ to $3 \%$, whereas in 
the case of cereals from $0.5 \%$ to even $6.6 \%$. The winter damage package is available from $1.8 \%$ for cereals and $3.6 \%$ for oilseeds. The most expensive was drought insurance, since the contribution was between $2 \%$ and $17 \%$ of the insured value in the case of maize. It can be assumed that this is the reason why insurance against this risk is practically not applicable in Poland.

Production practices such as irrigation, which are mentioned in the literature as an important factor determining taking out insurance policies, have not been included in the model as irrelevant in the Polish conditions where less than $0.05 \%$ of agricultural land is irrigated, mainly in horticultural farms that were excluded from the analysis. Similarly, participation in mutual funds was not taken into account since it is not used by Polish farmers at all. As mentioned earlier, price-stabilising measures were not analysed because they are neither a direct substitute for crop insurance, nor they are widely available in Poland.

The model has been estimated for farms from all over the country. The estimation was carried out in the R [R Core Team, 2015] environment, using the "survey" package [Lumley, 2014].

\subsection{Results}

The basic characteristics of farms in the analysed areas of the data set were calculated and shown in Table 3. Due to the FADN sampling method, each farm in the sample represents a different number of farms in the said population. The values shown in Table 3 shall be calculated as weighted averages, using the information about the number of farms in the population represented by each farm in the sample.

The characteristics presented in the Table indicate the differences in the characteristics of farms divided into quartile groups by subsidy rate. The main factor determining the amount of subsidies received is the farm size. The average farm size in all identified groups of farms is similar. On this basis, it can be assumed that the differentiation in terms of the subsidy rate will depend mainly on the production value per farms. This is confirmed by the results - the production value in the fourth quartile group is more than twice lower when compared to the first group. The lower production value on farms with the higher subsidy rate results from the poor soil quality and lower production intensity. When comparing the data for the $3^{\text {rd }}$ and $4^{\text {th }}$ quartile group with other farms, it can be observed that farming on poorer soils is subject to greater production risk. In the groups with the higher level of support, the percentage of farmers who at least once experienced a significant decrease in yields is also increasing. However, the share of farms which managed to receive compensation is significantly low- 
er than in the others, although in all the groups the share of insured farms is similar. The analysed groups of farms also differ in terms of the structure of production types. As the subsidy rate rises, the share of cereal farms increases, and in the fourth quartile group the share of mixed farms is strongly increased, at the expense of farms where the livestock production is dominant (TF 73-74).

Table 3. Characteristics of the population represented by farms in the sample in the FADN regions

\begin{tabular}{|c|c|c|c|c|c|}
\hline \multirow[b]{2}{*}{ Specification } & \multicolumn{4}{|c|}{ Quartile groups by subsidy rate } & \multirow{2}{*}{$\begin{array}{l}\text { Analysed } \\
\text { population } \\
\text { in total }\end{array}$} \\
\hline & $<14.9 \%$ & $\begin{array}{l}14.9- \\
-22.8 \%\end{array}$ & $\begin{array}{l}22.6- \\
-34.5 \%\end{array}$ & $>34.5 \%$ & \\
\hline UAA [ha] & 21.35 & 23.07 & 21.47 & 22.10 & 21.99 \\
\hline $\begin{array}{l}\text { Percentage of farms with insured } \\
\text { crops }[\% \text { of farms }]\end{array}$ & 20.83 & 19.81 & 20.67 & 17.23 & 19.53 \\
\hline $\begin{array}{l}\text { Farmers' level of education [\% of } \\
\text { farmers with secondary } \\
\text { or tertiary education] }\end{array}$ & 50.27 & 54.93 & 54.12 & 47.35 & 48.43 \\
\hline Age of a farmer [average] & 45.99 & 45.72 & 45.74 & 46.79 & 46.09 \\
\hline $\begin{array}{l}\text { Arrow-Pratt absolute risk } \\
\text { aversion coefficient }\end{array}$ & 1.41 & 1.47 & 1.51 & 1.56 & 1.49 \\
\hline Soil quality index [average] & 0.94 & 0.91 & 0.84 & 0.74 & 0.85 \\
\hline $\begin{array}{l}\text { Production intensity [average } \\
\text { value of inputs, } \\
\text { PLN thousand/ha] }\end{array}$ & 2.01 & 1.82 & 1.57 & 1.32 & 1.65 \\
\hline $\begin{array}{l}\text { Share of farms which received } \\
\text { compensation }[\%]\end{array}$ & 4.5 & 4.0 & 2.9 & 3.6 & 3.7 \\
\hline $\begin{array}{l}\text { Share of farms which experience } \\
\text { a significant }(>40 \%) \text { yield } \\
\text { decrease in } 2004-2012[\%]\end{array}$ & 15.9 & 17.3 & 20.2 & 23.0 & 19.4 \\
\hline Assets debt ratio* & 0.039 & 0.036 & 0.029 & 0.030 & 0.033 \\
\hline $\begin{array}{l}\text { Value of agricultural production } \\
\text { [average, PLN thousand] }\end{array}$ & 193.00 & 157.44 & 113.42 & 82.33 & 131.69 \\
\hline $\begin{array}{l}\text { Farm income [average, PLN } \\
\text { thousand] }\end{array}$ & 67.98 & 59.25 & 43.43 & 42.52 & 52.05 \\
\hline \begin{tabular}{|l|l|} 
& Cereal [TF15] \\
\cline { 2 - 2 }
\end{tabular} & 2.1 & 3.1 & 4.5 & 6.9 & 4.4 \\
\hline $\begin{array}{l}\text { Structure of } \\
\text { Cropping [TF16] }\end{array}$ & 11.0 & 7.3 & 6.9 & 9.7 & 8.6 \\
\hline farms in the $\begin{array}{l}\text { Cattle } \\
\text { [TF45-48] }\end{array}$ & 15.5 & 18.0 & 16.3 & 17.4 & 16.8 \\
\hline $\begin{array}{ll}\text { population } & \text { Mixed livestock } \\
\text { [percentage } & \begin{array}{l}\text { [TF73-74] } \\
\text { of farms in }\end{array}\end{array}$ & 31.8 & 27.3 & 31.5 & 17.7 & 26.7 \\
\hline $\begin{array}{ll}\text { the group] } & \text { Mixed } \\
\text { [TF 83-84] }\end{array}$ & 39.6 & 44.2 & 40.8 & 48.4 & 43.5 \\
\hline
\end{tabular}

Data for the population represented by the FADN sample calculated using the Horvitz-Thompson estimator; *value of liabilities/value of assets in total.

Source: own study. 
To show the impact of each analysed factor on the probability of taking out crop insurance, the authors calculated the average marginal effect of independent variables [discussion on calculating the marginal effect, cf. Greene 1997, p. 730]. The value of the average marginal impact on the quantitative variables can be interpreted as an average change in the probability of taking out crop insurance due to the growth of the individual variable by one unit.

In the case of the variable pointing to the location in the region, one level was selected as the reference point: "Pomorze and Mazury" region and the estimates presented show the result of the change in the farm region in relation to the level selected as a reference.

Analysis of the model's results was to clarify the factors determining taking out crop insurance. The estimates of the models for all analysed variables (relevant and irrelevant) for the whole country are shown in Table 4. The McFadden R2 for the estimated model was only $14.8 \%$, but the weighted percentage of proper forecasts was almost $82 \%$. The relatively high percentage of proper forecasts, the relatively small value of the McFadden R2 results from the very high share of uninsured farms in the analysed population.

Table 4. Estimation of the model of all Polish farms

\begin{tabular}{|l|c|c|c|c|}
\hline Variables & Estimation & SE & p-value & $\begin{array}{c}\text { Average } \\
\text { marginal } \\
\text { effect p.p. }\end{array}$ \\
\hline Absolute term & -2.7055 & 0.3667 & 0.000 & 0.00 \\
\hline Wielkopolska and Śląsk & 0.5924 & 0.1178 & 0.000 & 10.52 \\
\hline Mazowsze and Podlasie & -0.9186 & 0.1486 & 0.000 & -10.94 \\
\hline Małopolska and Pogórze & -0.5317 & 0.185 & 0.004 & -7.09 \\
\hline $\begin{array}{l}\text { Experiencing a significant } \\
\text { (>40\%) loss - [0/1] }\end{array}$ & 0.5702 & 0.0984 & 0.000 & 8.23 \\
\hline Soil quality index [0.05-1.95] & 0.6788 & 0.1493 & 0.000 & 10.37 \\
\hline $\begin{array}{l}\text { Production intensity } \\
\text { [PLN thousand/ha] }\end{array}$ & 0.2198 & 0.0747 & 0.003 & 3.05 \\
\hline Farm income [PLN thousand] & -0.0017 & 0.0007 & 0.020 & -0.02 \\
\hline Age of a farmer [year] & -0.0077 & 0.0045 & 0.087 & -0.10 \\
\hline Assets debt ratio & 1.1035 & 0.5121 & 0.031 & 18.12 \\
\hline $\begin{array}{l}\text { Receiving compensation } \\
\text { in 2004-2012 [0/1] }\end{array}$ & 1.1853 & 0.1999 & 0.000 & 19.71 \\
\hline $\begin{array}{l}\text { Arrow-Pratt absolute risk aversion } \\
\text { coefficient }\end{array}$ & 0.1455 & 0.1266 & 0.250 & 1.99 \\
\hline $\begin{array}{l}\text { Value of agricultural production } \\
\text { [average, PLN thousand] }\end{array}$ & 0.0021 & 0.0004 & 0.000 & 0.03 \\
\hline $\begin{array}{l}\text { Subsidy rate (operating subsidies/ } \\
\text { production value) }\end{array}$ & 0.3897 & 0.2256 & 0.084 & 5.62 \\
\hline
\end{tabular}

Source: own study. 
The results of the model show that there are significant differences between the regions in using crop insurance. The location of the farm in the Wielkopolska Voivodeship (790) has a strong positive effect on the probability of crop insurance and farmers in the southern, mountainous regions (800) of the country insure their crops less frequently. The difference between the probabilities of the average farm in these two regions with crop insurance is about 20 percentage points.

The experience of serious crop losses $(>40 \%$ of the average in the last 9 years) increases the probability of taking out crop insurance by more than 8 percentage points. The even more important factor positively affecting taking out crop insurance is the receipt of compensation in the past, which increases the probability of taking out insurance by 20 percentage points.

The results of the model also indicate that the soil quality and production intensity, and thus the expected production value, have a positive impact on the crop insurance decision. It can be concluded that the higher is the expected crop production value, the more farmers will actively manage the production risk through the use of crop insurance. Also, the farm debt level in relation to the asset value positively affects the probability of taking out crop insurance. Although the results of the model indicate the direction of changes in the probability of taking out a policy when changing individual factors, assuming that the remaining factors remain unchanged, it can be argued that farmers with the intensive production, who either perform or completed modernisation processes in their farm, will be more willing to take out a policy.

On the other hand, the income level negatively affects the probability of taking out crop insurance. It can, therefore, be concluded that farmers gaining the low and average income level are more likely to insure. Although, the average marginal effect shows that, on average, gaining income higher by PLN 100 thousand would lower the probability of concluding an insurance contract by only 2 percentage points. Bearing in mind the average income level for the analysed farms (Table 3), income cannot be indicated as a key factor.

In the model drawn up for the entire Poland, the factors such as the age of the farmer, Arrow-Pratt risk aversion coefficient and subsidy rate were not significant at the level of 0.05 .

In order to analyse more thoroughly the impact of subsidies on insurance decisions of farmers, further models were built for subgroups of farms identified according to the subsidy rate for farms (Table 5). Farms were grouped into four quartile groups as a division criterion using the value of the subsidy rate for farms. 
Table 5. Estimation of the model for farms divided into quartile groups by subsidy rate

\begin{tabular}{|l|c|c|c|c|}
\hline $\begin{array}{r}\text { Quartile groups } \\
\text { (subsidy rate) }\end{array}$ & $\begin{array}{c}1^{\text {st }} \text { group } \\
<14.9 \%\end{array}$ & $\begin{array}{c}2^{\text {nd }} \text { group } \\
14.9-22.8 \%\end{array}$ & $\begin{array}{c}3^{\text {rd }} \text { group } \\
22.6-34.5 \%\end{array}$ & $\begin{array}{c}4^{\text {th }} \text { group } \\
>34.5 \%\end{array}$ \\
Analysed variables & - & - & $10.20^{* *}$ & $14.53^{* *}$ \\
\hline Wielkopolska and Śląsk & $-15.62^{* *}$ & $-18.25^{* *}$ & $-12.59^{* *}$ & - \\
\hline Mazowsze and Podlasie & - & $-13.90^{* *}$ & $-11.49^{* *}$ & - \\
\hline Małopolska and Pogórze & $13.87^{* *}$ & $8.54^{* *}$ & $4.66^{*}$ & $4.94^{* *}$ \\
\hline Experiencing yield losses [0/1] & - & $15.54^{* *}$ & $8.30^{*}$ & $11.51^{* *}$ \\
\hline Soil quality index [0.05-1.95] & - & $3.65^{*}$ & $4.62^{*}$ & $7.34^{* *}$ \\
\hline $\begin{array}{l}\text { Production intensity } \\
\text { [PLN thousand/ha] }\end{array}$ & $-0.07^{* *}$ & - & - & - \\
\hline Farm income [PLN thousand] & - & - & - & - \\
\hline Age of the farmer [years] & - & - & $34.14^{*}$ & - \\
\hline Wskaźnik zadłużenia aktywów & $15.59^{* *}$ & $12.49^{* *}$ & - & $39.18^{* *}$ \\
\hline $\begin{array}{l}\text { Receiving compensation } \\
\text { in 2004-2012 [0/1] }\end{array}$ & - & - & - & - \\
\hline $\begin{array}{l}\text { Arrow-Pratt absolute risk aversion } \\
\text { coefficient }\end{array}$ & $0.05^{* *}$ & $0.03^{* *}$ & $0.03^{*}$ & $0.03^{* *}$ \\
\hline $\begin{array}{l}\text { Value of agricultural production } \\
\text { [thousand PLN] }\end{array}$ & & & & \\
\hline
\end{tabular}

** p-value $<0.05 ; *$ p-value $<0.1 ;$ "-" p-value $>0.1$

Source: own study.

The results of the individual models assessed for groups of farms divided by level of support partially confirm the dependencies observed during model analysis for the entire Poland. The location of a farm in the Wielkopolska and Śląsk region significantly increases the probability of taking out a policy. At the other extreme, we can place farms from the Mazowsze and Podlasie and Małopolska and Pogórze regions, which are much less willing to take out insurance. Nevertheless, on a basis of the estimates obtained for the variables defining the FADN region, it is not possible to indicate clearly the relationship between the subsidy rate and the tendency to insure crops.

Just like in the case of the country-wide model, the increase in the value of agricultural production increases the farmers' tendency to take out insurance, but also in this case the strength and direction of this relationship is very similar in all four models.

But then, we can observe a decreasing impact of experience of significant yield losses on the probability of taking out insurance as the subsidy rate increases. Experience of a significant yield loss on farms with the lowest substitution rate increases the chances of concluding a crop insurance contract. This confirms the results of previous studies [Majewski and Wąs, 2009] indicating the importance of subsidies in reducing the income risk. 
The statistically significant negative impact of the income level on the probability of taking out insurance was observed only in the group of farms with the lowest level of support. This may indicate that the statistically significant relationship between taking out insurance and income is observable only in the event of a low impact of subsidies on income.

We may also observe the growing, along with the level of support, impact of the production intensity on the decision on crop insurance. For less-supported farms ( $2^{\text {nd }}$ group of farms), it is more than twice lower than in the group with the highest subsidy rate. It can be assumed that more supported farms are characterised by a significantly faster growth and development, which is conducive to increasing the production intensity, but also, due to the higher expected yields, increases the risk of failure in the crop cultivation.

\subsection{Summary and conclusions}

The article analysed the factors determining the demand for crop insurance in Poland using a large set of data on farms in 2004-2013. The main factors determining the conclusion of crop insurance contracts are associated with the farmers' experiences such as: suffering significant yield losses in the past, receiving compensation. Additionally, an important factor determining taking out insurance is the location of a farm. Most other analysed determinants are slightly less important, however, the observed relationships are largely consistent with the results of previous studies. The factors such as the value of agricultural production, cultivation intensity, quality of soils which, according to the literature, increase the expected loss value have a positive impact on the uptake of insurance, particularly when they are correlated with lower income. In this case, the observed economic conditions are consistent with the expected utility hypothesis.

Contrary to the expectations, the characteristics of the farmer, such as the level of education, age and even risk aversion have not been verified as statistically significant at a significance level of $5 \%$. It is not possible to prove that farmers with tertiary education or with the Arrow-Pratt absolut risk aversion took out insurance more frequently than others. Also, at the national level, the impact of the subsidy rate on the willingness to take out insurance cannot be confirmed.

However, analysis of the results of the models on farms with various levels of support shows that the experience of a significant decrease in the past yields affects the decisions of farmers much more on farms with a relatively low level of support. This is confirmed by observations known from previous studies stipulating that direct payments and similar instruments stabilise farm income and thus reduce a need to insure crops. 
However, bearing in mind that among all the factors analysed, the receipt of compensation is the main determinant of using crop insurance, although there is no clear evidence it could be argued that the crop insurance subsidy scheme in Poland should be particularly focused on encouraging farmers who have not previously used insurance to join the scheme. This would give an opportunity to gain experience and would create a chance to be positively strengthened by receiving compensation in the event of a significant yield loss.

\section{References}

1. Aditya, K.S., Tajuddin, K.M., Kishore, A. (2016). Crop insurance in India: Drivers and impact. Agricultural and Applied Economics Association 2016 Annual Meeting, July 31-August 2, Boston, MA. available at: http://purl.umn.edu/235708.

2. Afroz, R., Akhtar, R., Farhana, P. (2017). Willingness to Pay for Crop Insurance to Adapt Flood Risk by Malaysian Farmers: An Empirical Investigation of Kedah, International Journal of Economics and Financial Issues, vol. 7 no. 4, pp.1-9.

3. Akinola, B. D. (2014). Determinants of Farmers' Adoption of Agriculture Insurance: the Case of Poultry Farmers in Abeokuta Metropolis of Ogun State, Nigeria, British Journal of Poultry, Vol. 3 No. 2 pp. 36-41.

4. Antle, J. M. (1987). Econometric Estimation of Producers' Risk Attitudes, American Journal of Agricultural Economics, Vol. 69, pp. 509-522.

5. Barry, P.J., Escalante, C.L., Bard, S.K. (2001). Economic Risk and the Structural Characteristics of Farm Businesses, Agricultural Finance Review, Vol. 61 No. 1, pp. 74-86.

6. Bielza Diaz-Caneja, M., Conte, C.G., Gallego Pinilla, F.J., Stroblmair, J., Catenaro, R., Dittmann, C. (2009). Risk management and agricultural insurance schemes in Europe, JRC Reference Reports 51982, EUR 23943 EN, Joint Research of European Commission, Ispra, Włochy.

7. Coble, K., Barnett, B. (2013). Why do we subsidize crop insurance?, American Journal of Agricultural Economics, Vol. 95 No. 2, pp. 498-504.

8. Coble, K.H., Knight, T.O., Pope, R.D., Williams, J.R. (1996). Modeling Farm Level Crop Insurance Demand with Panel Data. American Journal of Agricultural Economics, Vol. 78, No. 2, pp. 439-447.

9. European Commission (2001). Risk management tools for EU agriculture, with special focus on insurance, Working Document, DG Agriculture, Bruksela.

10.European Commission (2006). Agricultural insurance schemes, Joint Research Centre, Ispra, Włochy.

11.European Commission (2008). Regulation establishing a Community typology for agricultural holdings, No. 1242/2008, 8 December 2008, Bruksela.

12.European Commission (2009). Regulation concerning the selection of returning holdings for the purpose of determining incomes of agricultural holdings, No. 1291/2009, 18 December 2009, Bruksela.

13. European Commission (2010). Definitions of Variables used in FADN standard results, Community Committee for the Farm Accountancy Data Network (FADN). DG Agriculture, Bruksela. 
14. European Commission (2011). The future of CAP market measures, Agricultural Policy Perspectives Briefs, Brief no 3, DG Agriculture.

15. European Commission (2013). Regulation (EU) No. 1305/2013 of the European Parliament and of the Council of 17 December 2013 on support for rural development by the European Agricultural Fund for Rural Development (EAFRD) and repealing Council Regulation (EC) No 1698/2005.

16. Esuola, A., Hoy, M., Islam, Z., Turvey, C.G. (2007). Evaluating the effects of asymmetric information in a model of crop insurance, Agricultural Finance Review, Vol. 67 No.2, pp.341-356.

17.Farrin, K., Miranda, M. J., O’Donoghue, E. (2016). How Do Time and Money Affect Agricultural Insurance Uptake? A New Approach to Farm Risk Management Analysis, report summary: ERR-212, U.S. Department of Agriculture, Economic Research Service, August 2016.

18. Gardebroek, C., Chavez, M.D., Oude Lansink, A.G.J.M. (2010). Analysing production technology and risk in organic and conventional Dutch arable farming using panel data, Journal of Agricultural Economics, Vol. 61, pp. 60-75.

19. Goodwin, B.K. (1993). An Empirical Analysis of the Demand for Multiple Peril Crop Insurance, American Journal of Agricultural Economics, Vol. 75, No.2, pp. 425-434.

20. Goodwin, B.K., Mishra, A.K. (2006). Revenue Insurance Purchase Decisions of Farmers, Applied Economics, Vol. 38, No. 2, pp. 149-159.

21. Goodwin, B.K. (1993). An Empirical Analysis of the Demand for Multiple Peril Crop Insurance. American Journal of Agricultural Economics, Vol. 75, No. 2, pp. 425-434.

22. Goodwin, B.K., Vandeveer, M.L., Deal, J.L. (2004). An Empirical Analysis of Acreage Effects of Participation in the Federal Crop Insurance Program, American Journal of Agricultural Economics, Vol. 86 No. 4, pp. 1058-1077.

23. Greene, W.H. (1997). Econometric Analysis, 3rd ed., Prentice Hall, Upper Saddle River, New Jersey, NJ.

24. GUS (2015). Polski rynek ubezpieczeniowy, GUS, Warszawa.

25. GUS (2016). Charakterystyka Gospodarstw Rolniczych, GUS, Warszawa.

26. Hardaker, J.B., Huirne, R.B.M., Anderson, J.R. (1997). Coping with Risk in Agriculture, $\mathrm{CAB}$ International, Wallingford, UK.

27.Heerman, K.E.R., Cooper, J.,Johansson R., Worth T. (2016). Farmer response to crop insurance incentives under heterogeneous risk-management strategies 2016, Agricultural and Applied Economics Association Annual Meeting, July 31August 2, Boston, Massachusetts, available at: http://purl.umn.edu/235967.

28. Kobus P., Was A. (2017). Changes in Polish Farmers' Attitudes Toward Risk After Poland's Accession to the EU, Journal of Food Products Marketing, Vol. 23 , No. 4, pp. 357-366.

29. Kong, R., Turvey, C.G., He, G., Ma, J., Meagher, P. (2011). Factors influencing Shaanxi and Gansu farmers' willingness to purchase weather insurance, China Agricultural Economic Review, Vol. 3 No. 4, pp. 423-440. 
30. Kulawik, J, Płonka R. (2013). Subsydia a efektywność ekonomiczno-finansowa gospodarstw rolnych osób fizycznych, Zagadnienia Ekonomiki Rolnej, 2013;Vol. 336 No.3 pp.25-43.

31. Liesivaara, P., Myyrä, S. (2017). The demand for public-private crop insurance and government disaster relief, Journal of Policy Modeling, Vol. 39, No. 1, pp. 19-34.

32. Liu, B., Li, M., Guo, Y. and Shan, K. (2010). Analysis of the demand for weather index agricultural insurance on household level in Anhui, China, in $\mathrm{Xu}, \mathrm{S}$., Zhang, Q., Chen, k., Boyd, M. (Ed.), Agriculture and Agricultural Science Procedia, Vol. 1, Elsevier, Beijing, China, pp. 179-186.

33. Lumley, T. (2014). Survey: analysis of complex survey samples, R package version 3.30, available at: https://www.jstatsoft.org/article/view/v009i08.

34. Mohammed, M.A., Ortmann, G.F. (2005). Factors influencing adoption of livestock insurance by commercial dairy farmers in three Zobatat of Eritrea, Agrekon, Vol. 44 No. 2, pp. 172-186.

35. Majewski, E., Wąs, A., (2009). Znaczenie płatności bezpośrednich jako czynnika stabilizującego dochód rolniczy na przykładzie wybranych typów gospodarstw, Zeszyty Naukowe SGGW w Warszawie. Polityki Europejskie, Finanse i Marketing, 2009, Vol 51. No.2, pp. 235-248.

36. Masara, C., Dube, L. (2017). Socio-economic Factors Influencing Uptake of Agricultural Insurance by smallholder maize farmers in Girimonzi district of Zimbabwe, Journal of Agricultural Economics and Rural Development, Vol 3, No. 1, pp. 160-166.

37. Meuwissen, M.P.M., Assefa, T.T., van Asseldonk, M.A.P.M. (2013). Supporting insurance in European agriculture: Experience of mutuals in the Netherlands, Eurochoices, Vol.12 No.3, pp. 10-16.

38. O'Donoghue, E.J. (2014). The Effects of Premium Subsidies on Demand for Crop Insurance, Economic Research Report No. 169, U.S. Department of Agriculture, Economic Research Service, July 2014.

39. Mishra, A.K., Nimon, R.W., El-Osta, H.S. (2005). Is moral hazard good for the environment? Revenue insurance and chemical input use, Journal of Environmental Management, Vol. 74, pp. 11-20.

40. Parkin, M., Powell, M., Matthews, K. (2002). Economics, Harlow, Addison-Wesley.

41. R Core Team (2015). R: A language and environment for statistical computing, R Foundation for Statistical Computing, Vienna, Austria, available at: http://www.R-project.org/.

42. Roth, J., McCord, M.J. (2008). Agricultural microinsurance: global practices and prospects, Microinsurance Centre, Appleton, Wisconsin.

43. Sadati, S.A., Ghobsdi, F.R., Mohamadi, Y., Sharifi, O., Asakereh, A. (2010). Survey of effective factors on adoption of crop insurance among farmers: A case study of Behbahan County, African Journal of Agriculture Research, Vol. 5, No. 16, pp. 2237-2242.

44. Scandizzo, P.L. (2013). Securitizing Area Insurance: A Risk Management Approach, Journal of Financial Risk Management, 2013. Vol.2, No.3, pp. 55-60, Published Online September 2013 in SciRes, available at: http://www.scirp.org/ journal/jfrm . 
45. Serra, T., Goodwin, B.K., Featherstone, A.M. (2003). Modeling Changes in the U.S. Demand for Crop Insurance During the 1990s, Agricultural Finance Review, Vol. 63, No. 2, pp. 109-125.

46. Shaik, S., Coble, K.H., Knight, T.O., Baquet, A.E., Patrick, G.F. (2008). Crop Revenue and Yield Insurance Demand: a Subjective Probability Approach, Journal of Agricultural and Applied Economics, Vol. 40, No. 3, pp. 757-66.

47. Sherrick, B.J., Barry, P.J., Ellinger, P.N., Schnitkey, G. (2004). Factors Influencing Farmers' Crop Insurance Decisions. American Journal of Agricultural Economics, Vol. 86 No. 1, pp. 103-114.

48. Sherrick, B., Schnitkey, G. (2016). Crop Insurance Decisions for 2016, Farmdoc daily (6):40, Department of Agricultural and Consumer Economics, University of Illinois at Urbana-Champaign, Urbana-Champaign, IL, March 1, 2016 , available at: permalink:http://farmdocdaily.illinois.edu/2016/03/crop-insurance-decisionsfor-2016.html.

49. Smith, V.H., Glauber, J.W. (2012). Agricultural insurance in developed countries: Where have we been and where are we going?, Applied Economic Perspectives and Policy, Vol. 34, No. 3, pp. 363-390.

50. Smith, V.H., Goodwin, B. (1996). Crop Insurance, Moral Hazard, and Agricultural Chemical Use, American Journal of Agricultural Economics, Vol. 78 No. 2, pp. 428-438.

51. Smith, V.H.,Baquet, A.E. (1996). The Demand for Multiple Peril Crop Insurance: Evidence from Montana Wheat Farms. American Journal of Agricultural Economics Vol. 78 No. 1, pp. 189-201.

52. Solon, G., Haider, S.J., Wooldridge, J.M. (2015). What Are We Weighting For?, J. Human Resources, Vol. 50, no. 2, pp. 301-316.

53. Stempel, R. (2013). Ubezpieczenie upraw polowych na terenie Polski północnej.(eng. Field crop insurance in Northern Poland), Ubezpieczenia w rolnictwie materiały i studia, Vol. 47, pp.7-22.

54. Sulewski, P. (2009). Rolnicy wobec ryzyka i potrzeby ubezpieczeń - opinie i postawy, Roczniki Nauk Rolniczych, Seria G, Vol.96, No. 3, pp. 320-328.

55. Sulewski, P., Kłoczko-Gajewska, A. (2014a). Determinants of taking out insurance against losses in agricultural production in Poland, Annals of Agricultural Economics and Rural Development, Vol 101, No. 4. pp. 127-135.

56. Sulewski, P., Kłoczko-Gajewska, A. (2014b). Farmers' risk perception, risk aversion and strategies to cope with production risk: an empirical study from Poland, Studies in Agricultural Economics, Vol. 116, No. 3, pp. 140-147.

57. Sulewski, P., Majewski, E., Meuwissen, M., (2014). Fundusze ubezpieczeń wzajemnych jako forma ograniczania ryzyka w rolnictwie, Zagadnienia Ekonomiki Rolnej, Vol.339, No. 2, pp. 127-144.

58. Sun, B., Guo, C., van Kooten, G.C. (2014). Hedging weather risk for corn production in Northeastern China: The efficiency of weather-indexed insurance Sun, Agricultural Finance Review; Vol. 74, Issue 4, pp. 555-572.

59. Tsikirayi, R., Mazwi, C., Makoni, E., Matiza, J. (2013). Analysis of the uptake of agricultural insurance services by the agricultural sector in Zimbabwe, Journal of International Bissiness and Cultural Studies, Vol 7, p.207-221. 
60. Turvey, C.G., Kong, R. (2010). Weather risk and the viability of weather insurance in China's Gansu, Shaanxi, and Henan province, China Agricultural Economic Review, Vol. 2 No. 1, pp. 5-24.

61.Vavra, P. (2009). Role, Usage and Motivation for Contracting in Agriculture, OECD Food, Agriculture and Fisheries Working Papers, No. 16, OECD Publishing, Paris.

62. Velandia, M, Roderick, M., Rejesus, T., Knight, O., Sherrick, B.J. (2009). Factors Affecting Farmers' Utilization of Agricultural Risk Management Tools: The Case of Crop Insurance, Forward Contracting, and Spreading Sales, Journal of Agricultural and Applied Economics, Vol. 41, No. 1, pp. 107-123.

63. Wicka, A. (ed.), Gołębiewska, B., Gołębiewski, J., Jędrzejczyk, I., Kobus, P.,Wicki. L., Wojciechowska-Lipka, E., Wódkowski, A. (2013). Czynniki i możliwości ograniczania ryzyka w produkcji roślinnej poprzez ubezpieczenia, SGGW Warszawa.

64. Wooldridge, J.M. (1999). Asymptotic Properties of Weighted M-Estimators for Variable Probability Samples, Econometrica, Vol. 67, No. 6, pp. 1385-1406. 